\title{
Stress Level of Working and Non Working Women
}

\author{
Muddanagouda Patil ${ }^{1 *}$
}

\section{ABSTRACT}

Stress is a part of modern life, with increasing complexity of life, stress is likely to increase. Stress is built in the concept of role, which is conceived as the position a person occupies in a system. Women's in modern global world have to play a dual role as housewife and career builder. The present investigation was conducted to examine the stress among the working and non workingwomen's. It was hypothesized that the working women's has more stress than the non- working women's. In order to verify the above hypothesis a sample of 90 women's were taken. From which working women's ( $N=45)$ and non workingwomen's $(\mathrm{N}=45)$. To measure the stress, the stress scale developed by DR. M. Singh (2002) was administrated individually to the subjects. The data were subjected to ' $\mathrm{t}$ ' analysis and the major findings of the study reveals that the working women’s has more stress than the non workingwomen's.

Keywords: Stress, Working Women's And Non Working Women's

In modern times, higher education facilitated women's entry into gainful employment. But now a day everyone talks about stress. Not only just high pressure executives are its key victims but it also includes laborers, slum dwellers, working women's, businessmen, professionals and even children. Stress is an inevitable and unavoidable component of life due to increasing complexities and competitiveness in living standards. In the fast changing world of today, no individual is free from stress and no profession is stress free. Everyone experiences stress, whether it is within the family, business, organization, study, work, or any other social or economical activity. Thus in modern time, stress in general and job stress in particular has become a part of the life and has received considerable attention in recent years. Stress is a subject which is hard to avoid. Stress is a part of day to day living.

For centuries, women's have been expected to fulfill the ideal role of both perfect wife and mother, and this meant putting the family first before their own needs. If for whatever reason, a woman acted out of the norm chose to speak her mind, chose to work outside the home then her husband was criticized for not handling her properly. For example, if there is a newborn in the

\footnotetext{
${ }^{1}$ Research Scholar, Department of Psychology, Karnatak University, Dharwad, India

*Responding Author

(C) 2016 I M Patil; licensee IJIP. This is an Open Access Research distributed under the terms of the Creative Commons Attribution License (http://creativecommons.org/licenses/by/2.0), which permits unrestricted use, distribution, and reproduction in any Medium, provided the original work is properly cited.
} 


\section{Stress Level of Working and Non Working Women}

family, and the mother chooses to go back to work immediately after its birth, she is told by society that she's not doing her real job. Society doesn't criticize the father for leaving a newborn child to attend work; he is, in fact, applauded for considering the financial needs of his family an argument has been set forth that since women's can breastfeed, they must for the health and proper development of the child stay home during the early stages of childhood. Thus, the woman is placed in the difficult position of having to balance the multiple roles expected of her with the roles she wants to carry out for herself.

Women's are also encouraged to take up the stereotypical jobs such as secretarial, clerical, nursing, childcare, social work, elementary teaching and so forth. Most women's take on a typical 9-5 office workday so that they can be home to cook dinner, do the laundry and oversee the children's homework; they come home to a second shift. There has been an established ideology of what jobs are suitable for working mothers and what aren't. Being a secretary of a business is logically suitable. Being a businesswoman, meanwhile, will take too much time away from her family, and thus was not a logical path for a mother. Women's should be nurses, and not doctors; they surely could not be on call $24 \times 7$.

There are those who like their wives to have a mind of their own. With the help of the husband, women's can find freedom and happiness and a happy woman is a happy wife and mother! With the support of the husband, the wife feels as though she has backup and can venture into new fields. If the husband does not want to help, then she has to worry about who's going to cook, who's going to clean the house, who's going to take care of the children and so forth. Women's should not need permission from their husbands to work, but they surely need their support.

A significant number of women's believe that women's must stay at home and place the family before themselves. If there are women's who want to stay home instead of achieving success at the workforce, then it is their choice. For example, society shouldn't say a housewife is more respected than a working woman. They shouldn't say it is more suitable for a mother to be a nurse rather than a doctor. They shouldn't say that men being the breadwinners should be a priority. All should be given the equal opportunity and the equal compensation.

\section{Meaning of stress}

The concept of stress is very old even the pre-historic man might have experienced stress. Usually stress is experienced due to prolonged exposed to cold or heat, loss of blood, due to fear or any kind of diseases.

The word 'stress' defined by the oxford dictionary as "a state of affair involving demand on physical or mental energy”. 


\section{Stress Level of Working and Non Working Women}

\section{Concept of Stress}

The concept of stress was first introduced in the life sciences by 'Hans Selye' in 1936. It is a concept borrowed from the natural science. The concept of stress is derived form the Latin word 'stringer'.

\section{Definition}

Pascal (1992) defines stress in terms of perceived environmental situation which threatens the gratification of needs.

\section{LITERATURE REVIEW}

Bhattacharjee et, al. (1983) studied on family adjustment of married working and non working women's. A specially developed adjustment inventory, a health-status questionnaire, a neuroticism scale, and an incomplete sentences blank to 76 married working and 70 married nonworking women's. No significant differences in adjustment or neuroticism were found between the working and nonworking Ss, nor were any differences found on the incomplete sentences measure of psychological conflicts. It is concluded that a woman's adjustment, whether employed or not, is a function of her own personality traits, expectations, and perceptions combined with those of her spouse and family members.

Canlon .B. (1986) studied was examined the sexual dysfunction and disorder patterns of 218 married working and nonworking women's were compared in a retrospective analysis of couples presenting for sexual and marital therapy at the Masters \&3 Johnson Institute. Results indicated that women's who were pursuing careers of an ongoing, developmental nature were twice as likely to present with a primary complaint of inhibited sexual desire than women's who were employed in jobs that emphasized the immediate organization of activities) or women's who were unemployed outside of the home. "Career” women's were also significant4 more likely to present with veganism's than the other two groups of subjects. "Job” and "Unemployed" women's were more likely to complain of concerns related to orgasmic return than "career" subjects. The results were interpreted in terms of psychological and interpersonal stressors characteristic of married couples when wives pursue careers) and also in terms of the impact of traditional values regarding sexuality when wives are not involved in careers.

Hashmi Ahmed Hina (2007) studied was conducted to determine the marital adjustment, stress and depression among working and non working married women's. Sample of the study consisted of 150 working and non working married women's. Their education was at least gradation and above. They belong to middle and high socio-economic status. Results indicated highly significant relationship between marital adjustment, depression and stress. The findings of the results also show that working married women's have to face more problems in their married life as compared to non working married women's. The results further show that highly educated working and non working married women's can perform well in their married life and they are free from depression as compared to educated working and non working married women's. 
Khanna. S (1992) studied was conducted to determine life stress among working and nonworking women's in relation to anxiety and depression. Here sample $(\mathrm{N}=406)$ women's are defined from three located respectively, Jalandar (Panjab) and Simla (Hiachala Pradesh) in India. Correlation analysis reveals that: 1 . Anxiety is significantly and negatively related to positive life change in nonworking women's; 2 . Depression is significantly and positively related to positive life change in working women's, and negative life change in nonworking women's. These results suggest that in India, among working women's positive life changes are related to depression, whereas among nonworking women's positive life changes are related to anxiety, and negative life changes to depression.

Sanlier Nevin (2007) the study was conducted to examine in a sample of working and non working women's, the relationship between stress and working status. Data were gathered from 540 women's living in turkey. Mean, standard deviation, t test were performed. Stress system scale, stress related factors and total stress score were significantly associated with state of working. Family issues ( $p>0.001)$, environmental issues $(p<0.001)$., social self issues $(p<0.0010$. individual role issues $(\mathrm{p}, 0.001)$ and financial issues $(\mathrm{p}<0.001)$ in working women's, have a higher score than that of the non working women's. Working women's in the subscales of immune system $(\mathrm{p}<0.001)$ and susceptibility to stress scale have a higher average score than that of the non working. It has been determined that total stress score of working women's is higher compared to non working women's and that there is a significant difference between women's working status and total stress scores $(\mathrm{p}<0.001)$. Working women's have higher level of stress than non working women's. The results suggest that increased stress was associated with working status of Turkish women's.

Shirin Ahmad\& Nia (2002) studies had analyzed research on the impact of work on mothers' health in Tehran (Iran) within a role analytic framework. A survey was conducted of a representative sample of working and non working mothers in Tehran in 1998 (N=1065). Three main explanatory factors were examined alongside a range of mental and physical health outcome variables. Unlike in the West, where women's paid work is generally associated with better health, statistically significant differences between working and non working women's were not found in Tehran.

\section{RESEARCH METHODOLOGY}

\section{Objectives}

1. To explore the significant difference between working and non working women's in their stress.

2. To find out significant differences between married working and non working women's in their stress.

3. To find out significant differences between unmarried working and non working women's in their stress. 


\section{Hypothesis}

$\mathrm{Hy}_{1}$ : Working women's have significantly higher level of stress then non working women's.

$\mathrm{Hy}_{2}$ : Married working women's have higher level of stress then married non working women's.

$\mathrm{Hy}_{3}$ : Unmarried working women's have higher level of stress then unmarried non working women's.

\section{Sample}

The study was conducted on 90 sample included 45 working and 45 non workingwomen's from located Dharwad (Karnatak) in India.

\section{Tools}

Stress Scale by Dr. M. Singh (2002) this tool is self report questionnaire with 40 items. There are 3 responses category vise- always, anytime, and not at all. Reliability coefficient of the scale was estimated by split half method and test retest method and correlation was found to be 0.82 and 0.79 respectively. Validity coefficient was computed with Bist Battery of stress scale (Abha Rani Bist) and correlation was found to be 0.61 .

\section{Scoring}

Assign 2 marks for 'always', 1 mark for ' anytime' and 0 mark of 'not at all' sum up all the scores and interpret in terms of state of stress.

\section{Statistical Techniques}

After scoring the data, the raw scores were converted into standard scores using 16.0 versions of SPSS, subsequently the mean and SD was calculated. The data was subjected to independent sample ' $t$ ' analysis to find the significant difference between the working and non working women's.

\section{RESULTS AND DISCUSSION}

Table No 01: Mean, standard deviation and ' $t$ ' value of the working and Non workingwomen's on their stress.

\begin{tabular}{|l|l|l|l|}
\hline \multicolumn{5}{|c|}{ Sample Group (N=90) } \\
\hline Stress & $\begin{array}{l}\text { Working Women's } \\
(\mathrm{N}=45)\end{array}$ & $\begin{array}{l}\text { Non } \\
\text { Women's (N=45) }\end{array}$ & 't' value \\
\hline Mean & 37.64 & 10.20 & $4.34 * * *$ \\
\hline SD & 29.56 & 7.20 & \\
\hline
\end{tabular}

*** Very highly significant at 0.001

The table no 01 depicts means standard deviation, and ' $t$ ' value of the working women's and non workingwomen's on their stress. The mean and standard deviation scores of the working women's are 37.64 and 29.56 respectively. The mean and standard deviation score of the non workingwomen's are 10.20 and 7.20 respectively. The ' $t$ ' score obtain for the mean difference is 
4.34 which is very highly significant at 0.001 levels. This clearly implicate that the working women's have significantly very higher level of stress than non workingwomen's.

Table 02: Mean, standard deviation and 't' value of the married working and non working women's on their stress.

\begin{tabular}{|l|l|l|l|}
\hline \multicolumn{3}{|c|}{ Sample Group (N=54) } \\
\hline Stress & $\begin{array}{l}\text { Married Working } \\
\text { Women's }(\mathrm{N}=19)\end{array}$ & $\begin{array}{l}\text { Married Non Working } \\
\text { Women's (N=35) }\end{array}$ & 't' value \\
\hline Mean & 40.47 & 29.34 & \multirow{2}{*}{$4.46^{* * *}$} \\
\hline SD & 10.21 & 7.87 & \multirow{2}{*}{} \\
\hline
\end{tabular}

$* * *$ Very highly significant at 0.001

The table no 02 depicts means, standard deviation and ' $t$ ' value of the married working women's and married non working women's on their stress. The mean and standard deviation scores of the married working women's are 40.47 and 10.21 respectively. The mean and standard deviation scores of the married non working women's are 29.34 and 7.87 respectively. The ' $t$ ' scores obtained for the mean difference is 4.46 which is very highly significant at 0.001 levels. This clearly implicate that the married working women's have significantly very higher level of stress than married non working women's.

Table No 03: Mean, standard deviation and 't' value of the unmarried working and non working women's on their stress.

\begin{tabular}{|l|l|l|l|}
\hline \multicolumn{3}{|c|}{ Sample Group (n=32) } \\
\hline Stress & $\begin{array}{l}\text { Unmarried Working } \\
\text { Women's (N=22) }\end{array}$ & $\begin{array}{l}\text { Unmarried Non } \\
\text { Working Women's } \\
(\mathrm{N}=10)\end{array}$ \\
\hline Mean & 35.00 & 30.30 & \multirow{2}{*}{$1.41 \mathrm{NS}$} \\
\hline SD & 10.01 & 4.29 & \\
\hline
\end{tabular}

NS-Non significantly

The table no 03 shows means, standard deviation and ' $t$ ' value of the unmarried working and non working women's. On the stress there is no significant difference between unmarried working and non working women's. The obtained mean scores are 35.00 and 30.30 respectively. The obtained standard deviations are 10.01 and 4.29 respectively. The 't' value is 1.41 which is not significant.

\section{SUMMARY}

The present study is an attempt to know the level of stress of working and non workingwomen's, and to know the level of stress in relation to their status of married on working and non workingwomen's. 


\section{CONCLUSION}

1. This study has found out that working women's have significantly higher level of stress than non working women's.

2. Married working women's have significantly higher level of stress then married non working women's.

3. There is no significantly deference between unmarried working women's and unmarried non working women's

\section{REFERENCES}

Bhattacharjee, Pratima, Bhatt, k. Kusum.1983. Family adjustment of married working and non workingwomen’s. Indian journal of clinical psychology. Vol.10 (2). 497-501.

Canlon. B. 1986. Sexual dysfunction and disorder patterns of working and non working wives. Journal of sex and material therapy. Vol.12 (2). 93-107.

Duker, Jacob M. 1970. Housing and working wife families. A housing comparison land economics. Vol. 46(2), 138-145.

Ellen Hock. 1978. Working and non working mothers with infants. Journal of developmental psychol9ogy. Vol. 14(1), 37-43.

Hans Selye 1979. The stress of life. M C Graw hill. New York.

Heer, David. M.1962. Husband and wife perception of family, power, structure and family living. Vol. 24(1), 65-67.

Hoffman, Lois wadif.1960. Effect of the employment of mothers on parental power relation and the division of house hold tasks marriage and family living. Vol.22 (1), 27-35.

Pascal. 1992. Stress and coping. The Indian experience saga pat. New Delhi.

Ruth .e. Anderson, kulman.1986. Working mothers and the family context. Predicting positive coping. Journal of vocational behaviour. Vol.28 (3). 241-253.

Singal.W.R.1974. Journal of education an extension.

Singh M.(2002) Stress scale.

Spielberger C. 1979. Understanding stress and anxiety. New York. 